\title{
The Impact of Political Stability on the Effectiveness of the Early Warning Systems in Predicting the Financial Crises: The Case of Jordan and Qatar
}

\author{
Baker Shnekat ${ }^{1} \&$ Ghazi Al-Assaf ${ }^{1}$ \\ ${ }^{1}$ Business Economics Department, the University of Jordan, Amman, Jordan \\ Correspondence: Baker Shnekat, Business Economics Department, the University of Jordan, Amman, Jordan.
}

Received: April 1, 2020

Accepted: May 20, 2020

Online Published: July 7, 2020

doi:10.5430/ijfr.v11n4p398

URL: https://doi.org/10.5430/ijfr.v11n4p398

\begin{abstract}
The research aims to identify the impact of political stability in determining the effectiveness of early warning systems in predicting financial crises. The research applied a standard descriptive approach.

In general, when comparing the two countries before including the model for economic variables the results showed that the nature of the impact of economic variables is different as the index of the financial crisis in Jordan is affected by the import of goods and services while the most influential indicators in the early warning model for the occurrence of the financial crisis in Qatar is the index of exporting goods and services on the basis that the system Qatari financial is very sensitive to the subject of export of gas and oil. Also, the results showed that there is a very significant impact of political stability on the financial crisis, which is greater than the impact of economic indicators, and if the two countries differed in which indicators for political stability have the greatest impact on the occurrence of the financial crisis, in Jordan the most influential indicator was the government effectiveness variable in Qatar, the regulatory quality index was the most influential.
\end{abstract}

Keywords: political stability, early warning systems financial crises, Jordan, Qatar

\section{Introduction}

Over the last two decades, the world is exposed of many variables that lead to different type of financial crises. Thus, the phenomenon of financial crises in different countries of the world has become one of the relatively serious economic phenomena, due to its negative effects and threatening to the economic and political stability of countries experiencing such crises.

In addition, the root causes of these effects and the contagion of the financial crises are due to globalization, the revolution in communications and economic liberalization, which contributes to the increasing severity of the financial crisis on all countries, leading to recession. Accordingly, many countries seek to confront these different emergency conditions, by building and setting up different warning systems that it seeks to predict future events and their confrontations. Early warning indicators play a fundamental role in effective crisis management, as the correct orientation for predicting crises before they occur leads to avoiding crises and avoiding the losses that may occur from financial crises. In addition, early warning systems constitute play an important role in any country, it is considered as an essential tool that enables countries to face the changes, developments that occur in states. In addition to these systems constitute the basic line that different countries follow in order to avoid financial crises (Ari, 2012).

The twentieth century witnessed a number of financial crises, the most important of which were the 1929 crisis, the 1973 crisis, the 1987 crisis, and the Asian crisis of 1997 that struck many Asian countries, the most recent of which was the world. in late 2008, which is an important historical event by all standards, where what happened in the markets is considered Global finance is a real financial crisis, which has ravaged the economies of developed and developing countries alike. The signs of this crisis appeared in 2007 and emerged more in the year 2008, and the manifestations of the recent financial crisis were the cash liquidity crisis and the mortgage based on loans with poor creditworthiness, and its effects were reflected in all situations. As this crisis affected many political decisions, and it has struck It resulted in difficult social conditions represented by the loss of many workers and employees to their work centers and their livelihoods, and left severe psychological effects, as they did not affect a particular 
community, but included the whole world in varying proportions in its effects and repercussions.

Moreover, the financial crisis has brought serious features of political instability in many countries of the world, which posed a challenge to re-investigation and perhaps redefinition of some theoretical concepts. Political stability was considered one of the most important concepts of the new economic growth theory as political stability is very necessary and one of the most important thing. They are provided in order to achieve the conditions of economic growth, and there is no doubt that successful economic development will also be achievable in the context of political and institutional transformation as well as government changes (Kouba\&Grochová, 2009; Campos et al., 1999).

Despite of the issue of financial crises and political stability is a topic that is not relatively modern, the financial crises that rocked the developed and developing countries. In the recent period were very expensive for many countries in the world, as they led to a decline in economic growth rates in addition to an economic recession, and high rates Both poverty and unemployment; and although many countries of the world try to manage financial crises wisely and with the least possible loss, this is not sufficient. These crises need to determine the effectiveness of early warning systems to predict financial crises before they occur; therefore, this research came to highlight the impact of the effectiveness of early warning systems to anticipate financial crises in light of political stability.

This research aims to employ econometric technique to investigate the impact of political stability in determining the effectiveness of early warning systems in predicting the financial crises. The main methodology adopted in this study was based on the Multinomial Logit estimation using the data of Jordan and Qatar covering the period 1996-2016. This paper is an attempt to identify a number of leading indicators that can help our understanding of financial crises and their relationships with political stability environment.

\section{Literature Review}

Although the issue of financial crises has its roots in history, it has come back to present itself strongly with the increasing phenomenon of globalization, the financial crises that affected the developed and developing countries in recent decades it was costly in terms of economic slowdown, low growth rates, and high poverty rates and unemployment. Although crises management and wisdom and success are managed and mitigating their negative effects are extremely important, the most important and least costly is the success in adopting policies and procedures that help to prevent them and avoid their occurrence at all, and in this regard, early warning systems for crises are a permanent tool and continuing to direct and warn decision-makers and policymakers of the potential exposure of the economy to a financial crisis, by assessing the overall economic risk profile and developing response policies Rapid in the early stages of the crisis before its development, and then avoid the significant costs that may result in if it happens. As well as, the concept of political stability is linking with some social and political issues, as the phenomenon of stability, is related to social conflict and how it can lead to internal quarrels between members of society, whether that is at the economic level members of society.

Consequently, political stability is defined as the state of steadfastness, it is the extent of the people's government's ability to participate, reach or compete for power through non-violent political processes and enjoy the collective benefits and services of the state, and is based on providing basic services, managing state resources, civil participation and empowerment, political moderation and accountability (Çalışkan, 2019).

According to Kaufmann et al., (2010) the indicators of political stability that represented the global governance indicators (WGI)is a set of data summarizing views on the quality of governance provided.

On the other hand, early warning systems are considered one of the most important elements that contribute to reducing financial crises, as effective warning systems help in reducing losses and the economic and material effects of many financial crises and to ensure the effectiveness of early warning systems, it is necessary to create different conditions in order to take action early.

Moreover, the early warning system is a system that tries to predict the possibility of crises using multiple models taking into account a wide range of political and economic factors, such as low debt and short-term exchange rates that may lead to speculative attacks during political instability, economic slowdowns and ineffective regulatory environments, In addition to taking into account the role of government instability, corruption, high short-term debt, and unstable monetary and financial policies that may not only reduce investor confidence but also prevent and prevent effective strategies for crisis prevention (Tamadonejad, et al., 2016).

The International Monetary Fund also clarified that the early warning system is a set of economic models that are used by the Monetary Fund in order to predict financial crises before they occur, and these models are based on external fluctuations and the exploitation of the relationship that appears through historical data between the 
variables that cause the crises (Beckmann et al., 2006).

In most of the time, the economy at the macro level may be exposed to more than one crisis and this is called synchronization of crises, and one of the most important crises To which the international economy is exposed to the unemployment crisis that was accompanied by the occurrence of a global inflation crisis, and accordingly, the interconnected crises are the ones that occur as a result of the close link between the elements and events and their interaction with each other. For various reasons not related to each other.

Given the importance of the issue of political stability and its impact on financial crises and its relationship to early warning systems, a number of previous studies were reviewed. Al-Assaf (2017) study concluded that the real exchange rate (RER), money supply reserve ratio (M2R), domestic credit growth rate $(\triangle D C)$, the ratio of central bank external assets to liabilities ratio (AL), and export growth play an important role in the index Early warning systems. While (Boonman, 2017) applied two types of early warning systems: the signal approach and the logit model. The study reached a number of results, the most important of which is that, in both methods, it was found that the use of early estimates in predictions increases the poor ability of early warning systems to indicate crises compared to the most recent information available.

Moreover, Tamadonejad et al. (2016) study has found that short-term depreciation and exchange rates may lead to speculative attacks during political instability, economic slowdowns, and ineffective regulatory environments. The study also found that government instability, corruption, short-term high debt, and unstable monetary and tax policies not only reduce investor confidence but also prevent effective strategies to prevent crises. Therefore, by adopting a system of early warning systems, the government will be able to monitor the environmental changes that cause financial crises.

Additionally, Kamra (2013) study concluded that the crisis is largely explained by economic variables, which include external debt ratios that measure solvency and debt sustainability. , Non-liquidity measures or refinancing risks, external imbalances and debt service pressures (interest rates), as well as controls on gross domestic product. Finally, the results highlighted that financial systems with more effective and healthy commercial banks are better equipped to direct savings to investors Thus; they are less likely to enter the debt crisis.

Also, Al-Assaf et al. (2013), study found that the real exchange rate (RER) and the ratio Money supply reserve (M2R), domestic credit growth rate (CDC) and the ratio of the central bank's external assets to liabilities (AL) ratio, play an important role in clarifying financial crises.

Finally, Babecký et al. (2011) study found that asset price indicators and liquidity indicators are performing well for an effective practice of early warning systems; another important finding of the study is that the early warning system for financial crises needs warnings in order to reduce the occurrence of financial crises and reduce their impact.

Based on the above, the previous studies give out the issues of political stability, early warning systems, and financial crises in different countries and in different variables. As for the current study was focus mainly on the impact of political stability on the effectiveness of the early warning systems in predicting the financial crises in Jordan and Qatar, which was not previously addressed objectively and focused. Also, the importance of this study also lies in the fact that it covered the period from 1996 to 2018, and therefore the results of this study will be a reference for many studies.

\section{Data and Model Specification}

\subsection{Data}

The data used in the empirical analysis is a monthly data for both Jordan and Qatar. The reason behind selecting these two economies is that the two countries are in the Middle East region, which experienced many political crises, and a full data set is available for both countries. The data is covering the period January 1996 to December 2018.

A set of variables for measuring political stability has been studied and a set of financial indicators that form the early warning system and help to anticipate financial crises, namely:First - variables measuring political stability which includes (Voice and Accountability, Political Stability and Absence of Violence/Terrorism, Government Effectiveness, Regulatory Quality, Rule of Law, Control of Corruption. Second- variables measuring the financial crisis that make up the early warning system:

- The rate of inflation in consumer prices.

- The balance of payments index.

- The commodity and goods import index, 
- $\quad$ The GDP.

- The commodity import index.

- The commodity export index.

3.2 Methodology and Model Specification

The main methodology adopted in this paper is based on the multinomial logit model, the logit model relies on a set of economic and financial variables combined to construct the prediction model and gives a result (0), which means predicting that no crisis has occurred or (1) predicting a crisis, as logit models are used to model separate results.

Empirical studies are usually used to estimate the currency crisis methodology of the Discrete Dependent Variable in the form of a Probit model, in order to make a relation between the possibility of a currency crisis and a set of variables that may affect it. Estimating the probability of currency crises requires converting MP values to values 0 , and 1, to represent the dependent variable in the multinomial Logit model. The conversion procedure.

\subsection{Research Model}

The applied aspect will be with a logit model, which is a statistical methodology that mainly depends on predicting the most common values and these values are known as logistic regression.

The relationship between the indicators of political stability can be described and refer to (X) which are explanatory variables that include (the Voice and Accountability Index, the absence of violence/terrorism index, the government effectiveness index, the organizational quality index, the rule of law index, the corruption control index), and each of the Early warning indicators for financial crises indicate $Y$ (include the following: (the change in the exchange rate index, the current account / GDP deficit index, the foreign debt / GDP index, the real national demand growth rate indicator, and the short-term debt ratio to Gross debt, and interest rate index), on an effective improvement Mechanism of early warning systems through the logit model equation.

- $\quad$ Logit Formula Equation (Al-Assaf et al., 2013):

$$
\mathrm{P}(Y=1)=F(X \beta)=\frac{e^{X \beta}}{1+e^{X \beta}}=\frac{1}{1+e^{-X \beta}}=\log ^{-1}(X \beta)
$$

Where $(\mathrm{X})$ are explanatory variables, which includes (Voice and Accountability Index, Violence / Terrorism Absence Index, Government Effectiveness Index, Organizational Quality Index, Rule of Law Index, Corruption Control Index; and $\beta$ indicates the regression coefficient.

- $\quad$ The effect of variables on the likelihood of financial crises (Al-Assaf et al., 2013):

$$
\Omega(Y=1 \mid X)=\frac{P}{1-P}=e^{X \beta}
$$

Where $\mathrm{P}$ is the probability of a financial crisis

The proposed model is used to determine the main indicator and the following indicators were relied on: market pressure on the exchange rate (MPt), and wide money supply (M2 ) To the reserves ratio (M2Rt), the central bank's foreign assets to the ratio of foreign liabilities (AL), the price of a country's growth measured by its industrial production $(\triangle \mathrm{IP})$, the real exchange rate (RERt), the domestic credit growth rate (CDCt), and the rate of export growth $(\Delta \mathrm{Xt})$, import growth rate

\section{Empirical Results}

To measure the impact of political stability on the effectiveness of the early warning system, for the case of Jordan and Qatar covering the period 1996 to 2018 on a monthly base. The comparison is based on an estimate of the various leading indicators that help in forecasting currency crises in the countries under investigation. The estimation is then proceeded to determine the impact of political stability indicators on each of the indicators of early warning systems in financial crises using the logistic regression model, and the results are as follows:

\subsection{The Result of Jordan}

- The impact of the indicators of political stability on the indicator of the percentage of growth in GDP:

The indicator of the rate of growth in gross domestic product is one of the most important indicators in early warning systems. Before studying the impact of political stability indicators on this indicator, it is necessary to study the stillness of the indicators of political stability using the Dicky Fuller test developed and the Philip Peron test shown in the following table: 
Table 1. The stillness of the indicators of political stability using the Dicky Fuller test developed and the Philip Peron test

\begin{tabular}{|c|c|c|c|}
\hline \multirow{2}{*}{ variable } & & \multicolumn{2}{|c|}{ Jordan } \\
\hline & & ADF & PP \\
\hline Voice and Accountability & $\mathrm{x} 1$ & $-2.268507 * *$ & $-7.499439 * *$ \\
\hline $\begin{array}{c}\text { Political Stability and Absence of } \\
\text { Violence/Terrorism }\end{array}$ & $\mathrm{x} 2$ & $-8.022826 * *$ & $-9.077524 * *$ \\
\hline Government Effectiveness & $\mathrm{x} 3$ & $-4.562149 * *$ & $-6.640149 * *$ \\
\hline Regulatory Quality & $\mathrm{x} 4$ & $-7.704852 * *$ & $-10.22182 * *$ \\
\hline Rule of Law & $\mathrm{x} 5$ & $-5.365716^{* *}$ & $-5.494056^{* * *}$ \\
\hline Control of Corruption & x6 & $-5.390625 * *$ & $-5.535594 * *$ \\
\hline
\end{tabular}

The above table represented that the studied variables were indicators of political stability are stable.

- Results of the logistic regression model:

Table 2. The effect of early warning indicators on the financial crisis index in Jordan (model without political index)

\begin{tabular}{|c|c|c|c|}
\hline \multicolumn{4}{|c|}{ model without political index } \\
\hline Variable & \multicolumn{3}{|c|}{ Coefficient } \\
\hline & \multicolumn{3}{|c|}{$0.681301 * *$} \\
\hline $\mathrm{CAB}$ & \multicolumn{3}{|c|}{$(66.31)$} \\
\hline & \\
\hline GGG & \multicolumn{3}{|c|}{$(157.602)$} \\
\hline & \multicolumn{3}{|c|}{$1.446925 * *$} \\
\hline IAC & \multicolumn{3}{|c|}{$(162.69)$} \\
\hline & \multicolumn{3}{|c|}{$1.846299 * *$} \\
\hline EOG & \multicolumn{3}{|c|}{$(88.60)$} \\
\hline & \multicolumn{3}{|c|}{$-3.39956 * *$} \\
\hline EOGS & \multicolumn{3}{|c|}{$(-103.3)$} \\
\hline & \multicolumn{3}{|c|}{$-4.62284 * *$} \\
\hline IOG & \multicolumn{3}{|c|}{$(-114.53)$} \\
\hline & \multicolumn{3}{|c|}{$5.670626 * *$} \\
\hline IOGS & \multicolumn{3}{|c|}{$(107.34)$} \\
\hline & \multicolumn{3}{|c|}{$-241.338 * *$} \\
\hline $\mathrm{C}$ & \multicolumn{3}{|c|}{$(-106.08)$} \\
\hline McFadden R-squared & 1 & Mean dependent var & 0.65 \\
\hline S.D. dependent var & 0.48936 & S.E. of regression & $1.16 \mathrm{E}-17$ \\
\hline Akaike info criterion & 0.8 & Sum squared resid & $1.61 \mathrm{E}-33$ \\
\hline Schwarz criterion & 1.198293 & Log likelihood & 0 \\
\hline Hannan-Quinn criter. & 0.877751 & Deviance & 0 \\
\hline Restr. deviance & 25.89787 & Restr. log likelihood & -12.9489 \\
\hline LR statistic & 25.89787 & Avg. log likelihood & 0 \\
\hline Prob(LR statistic) & 0.000525 & & \\
\hline
\end{tabular}

The Table2 showed there is a significant effect of early warning indicators on the financial crisis index in Jordan, where the value of LR is 25.89 and the prob value is 0.000525 , which is less than 0.05 . The results also indicated that 
all indicators that constitute early warning are significant.

The results also show in the previous table that the most influential variables in the index of the financial crisis in Jordan is the variable for importing goods and services, while the least impact variables are the current account balance variable.

The following is the addition of the variables of political stability to determine their impact on the early warning model.

Table 3. The effect of early warning indicators on the financial crisis index in Jordan (model with political index)

\begin{tabular}{|c|c|c|c|}
\hline \multicolumn{4}{|c|}{ model with political index } \\
\hline Variable & & Coefficient & \\
\hline Voice and Accountability & & $\begin{array}{c}-88.64818 * * \\
(-25.24) \\
\end{array}$ & \\
\hline $\begin{array}{c}\text { Political Stability and Absence of } \\
\text { Violence/Terrorism }\end{array}$ & & $\begin{array}{c}-13.4946^{* *} \\
(-13.77)\end{array}$ & \\
\hline Government Effectiveness & & $\begin{array}{c}-136.2923 * * \\
(-77.40)\end{array}$ & \\
\hline Regulatory Quality & & $\begin{array}{l}65.0151 * * \\
(73.82)\end{array}$ & \\
\hline Rule of Law & & $\begin{array}{c}47.87114 * * \\
(35.06)\end{array}$ & \\
\hline Control of Corruption & & $\begin{array}{c}20.64148 * * \\
(32.34)\end{array}$ & \\
\hline CAB & & $\begin{array}{l}0.853038 * * \\
\quad(30.31)\end{array}$ & \\
\hline GGG & & $\begin{array}{l}1.283711 * * \\
(54.62)\end{array}$ & \\
\hline IAC & & $\begin{array}{c}0.30026^{* *} \\
(73.86)\end{array}$ & \\
\hline EOG & & $\begin{array}{c}1.305911 * * \\
(27.401)\end{array}$ & \\
\hline EOGS & & $\begin{array}{c}-3.453673 * * \\
(-29.71)\end{array}$ & \\
\hline IOG & & $\begin{array}{c}-6.034325^{* *} \\
(-34.35)\end{array}$ & \\
\hline IOGS & & $\begin{array}{c}6.844219 * * \\
(27.89)\end{array}$ & \\
\hline $\mathrm{C}$ & & $\begin{array}{c}-201.5608 * * \\
(-43.12) \\
\end{array}$ & \\
\hline McFadden R-squared & 1 & Mean dependent var & 0.65 \\
\hline S.D. dependent var & 0.48936 & S.E. of regression & $2.73 \mathrm{E}-17$ \\
\hline Akaike info criterion & 1.4 & Sum squared resid & $4.48 \mathrm{E}-33$ \\
\hline Schwarz criterion & 2.097013 & Log likelihood & 0 \\
\hline Hannan-Quinn criter. & 1.536064 & Deviance & 0 \\
\hline Restr. deviance & 25.89787 & Restr. log likelihood & -12.9489 \\
\hline LR statistic & 25.89787 & Avg. log likelihood & 0 \\
\hline Prob(LR statistic) & 0.017546 & & \\
\hline
\end{tabular}

The previous table shows the results of adding political stability variables to the logistical model, where it was found 
that there is a significant impact of the variables of political stability on the financial crisis, since taking into account the impact of other economic variables, it can be noted that the most influential variable on the financial crisis is a Government Effectiveness variable followed by the Voice and Accountability variable Then the Regulatory Quality variable and the role of economic variables declined to second place after the variables related to political stability, which indicates the great impact of political stability in Jordan on the occurrence of the financial crisis.

In general, the results of the table shows that there is a significant effect of the model's political stability variables on the early warning system in Jordan, as the prob value is significant for all variables studied.

\subsection{The Result of Qatar}

- The impact of the indicators of political stability on the indicator of the percentage of growth in GDP:

The indicator of the rate of growth in gross domestic product is one of the most important indicators in early warning systems. Before studying the impact of political stability indicators on this indicator, it is necessary to study the stillness of the indicators of political stability using the Dicky Fuller test developed and the Philip Peron test shown in the following table:

Table 4. The stillness of the indicators of political stability using the Dicky Fuller test developed and the Philip Peron test

\begin{tabular}{cccc}
\hline \multirow{2}{*}{ variable } & & \multicolumn{2}{c}{ Qatar } \\
\cline { 3 - 4 } & & ADF & PP \\
\hline Voice and Accountability & $\mathrm{x} 1$ & $-3.96662^{* *}$ & $-3.59471^{* *}$ \\
\hline $\begin{array}{c}\text { Political Stability and Absence of } \\
\text { Violence/Terrorism }\end{array}$ & $\mathrm{x} 2$ & $-6.42181^{* *}$ & $-7.29974^{* *}$ \\
\hline Government Effectiveness & $\mathrm{x} 3$ & $-4.82436^{* *}$ & $-4.87189^{* *}$ \\
\hline Regulatory Quality & $\mathrm{x} 4$ & $-4.92846^{* *}$ & $-4.99959^{* *}$ \\
\hline Rule of Law & $\mathrm{x} 5$ & $-6.5218^{* *}$ & $-6.52657^{* *}$ \\
\hline Control of Corruption & $\mathrm{x} 6$ & $-3.08266^{* *}$ & $-5.88681^{* *}$ \\
\hline
\end{tabular}

The above table represented that the studied variables were indicators of political stability are stable.

- Results of the logistic regression model:

Table 5. The effect of early warning indicators on the financial crisis index in Qatar (model without political index)

\begin{tabular}{cc}
\hline Variable & Coefficient \\
\hline & $0.737719^{* *}$ \\
CAB & $(76.82144)$ \\
\hline & $1.211679^{* *}$ \\
GGG & $(91.73)$ \\
\hline IAC & $0.827858^{* *}$ \\
& $(96.99)$ \\
\hline EOG & $2.593358^{* *}$ \\
EOGS & $(165.61)$ \\
\hline & $-5.179839^{* *}$ \\
IOG & $(-166.99)$ \\
\hline & $0.371226^{* *}$ \\
IOGS & $(51.97)$ \\
\hline
\end{tabular}


$-122.3889 * *$

$\mathrm{C}$

$(-111.79)$

\begin{tabular}{cccc}
\hline McFadden R-squared & 1 & Mean dependent var & 0.45 \\
\hline S.D. dependent var & 0.510418 & S.E. of regression & $8.88 \mathrm{E}-18$ \\
\hline Akaike info criterion & 0.8 & Sum squared resid & $9.46 \mathrm{E}-34$ \\
\hline Schwarz criterion & 1.198293 & Log likelihood & 0 \\
\hline Hannan-Quinn criter. & 0.877751 & Deviance & 0 \\
\hline Restr. deviance & 27.52555 & Restr. log likelihood & -13.7628 \\
\hline LR statistic & 27.52555 & Avg. log likelihood & 0 \\
\hline Prob(LR statistic) & 0.000268 & & \\
\hline
\end{tabular}

The results shows that there is a significant effect of early warning indicators on the financial crisis index in Qatar, where the value of LR is 25.89 and the prob value is 0.000525 which is less than 0.05 . The results also indicated that all indicators that constitute early warning are significant, and the following is by adding variables of political stability to stand on its impact on the early warning model.

As can be seen from the previous table, the most influential variable on the financial crisis index is the variable for exporting goods and services, followed by the variable for exporting goods.

Table 6. The effect of early warning indicators on the financial crisis index in Qatar (model with political index) model with political index

\begin{tabular}{cc}
\hline Variable & Coefficient \\
\hline Voice and Accountability & $45.89178^{* *}$ \\
& $(22.73)$ \\
\hline Political Stability and Absence of & $-49.99982^{* *}$ \\
Violence/Terrorism & $(-87.51)$ \\
\hline Government Effectiveness & $18.54229^{* *}$ \\
& $(26.10)$ \\
\hline Regulatory Quality & $75.42663^{* *}$ \\
Rule of Law & $(74.09)$ \\
\hline & $8.472354^{* *}$ \\
Control of Corruption & $(3.757)$ \\
\hline & $-24.19322^{* *}$ \\
CAB & $(-34.96)$ \\
\hline & $-0.598035^{* *}$ \\
GGG & $(-3478)$ \\
\hline & $-0.117292^{* *}$ \\
IAC & $(-10.28)$ \\
\hline EOG & -0.026293 \\
EOGS & $(-0.82)$ \\
\hline & $-2.223184^{* *}$ \\
& $(-91.68)$ \\
\hline & $1.954223^{* *}$ \\
& $(81.55)$ \\
\hline & $-0.7278^{* *}$ \\
\hline & $(-97.91)$ \\
\hline
\end{tabular}




\begin{tabular}{|c|c|c|c|}
\hline \multirow[b]{2}{*}{ IOGS } & \multicolumn{3}{|c|}{$0.605262 * *$} \\
\hline & \multicolumn{3}{|c|}{$(89.82)$} \\
\hline & \multicolumn{3}{|c|}{$77.23015 * *$} \\
\hline $\mathrm{C}$ & \multicolumn{3}{|c|}{$(68.13)$} \\
\hline McFadden R-squared & 1 & Mean dependent var & 0.45 \\
\hline S.D. dependent var & 0.510418 & S.E. of regression & $1.70 \mathrm{E}-17$ \\
\hline Akaike info criterion & 1.4 & Sum squared resid & $1.73 \mathrm{E}-33$ \\
\hline Schwarz criterion & 2.097013 & Log likelihood & 0 \\
\hline Hannan-Quinn criter. & 1.536064 & Deviance & 0 \\
\hline Restr. deviance & 27.52555 & Restr. log likelihood & -13.7628 \\
\hline LR statistic & 27.52555 & Avg. log likelihood & 0 \\
\hline Prob(LR statistic) & 0.010533 & & \\
\hline
\end{tabular}

The previous table shows the results of adding political stability variables to the logistical model, where it was found that there was a significant impact of the variables of political stability on the financial crisis, since taking into account the impact of other economic variables, it can be noted that the most influential variables on the financial crisis is a Regulatory Quality variable followed by a Political Stability and variable Absence of Violence / Terrorism, then the Voice and Accountability variable, and the role of economic variables declined to second place after the variables related to political stability, which indicates the great impact of political stability in Qatar on the occurrence of the financial crisis. In general, the results indicate that the variables of political stability in the model have a significant effect on the early warning system in Qatar, as the prob value is significant for all variables studied.

\section{Conclusion}

This research is an attempt to explain the impact of the effectiveness of early warning systems to anticipate financial crises in light of political stability in Jordan and Qatar. To achieve this objective, an MP index was constructed and employed in a multinomial Logit model, using data for Jordan and Qatar covering the period from January 1996 to December 2018.

The analysis used in this paper is based on transforming the MP to a binary variable and include it in our estimation. From the main empirical results, it is concluded that the political stability variable plays a significant role in explaining the effectiveness of the early warning system, for Jordan and Qatar.

The empirical results show that the political stability variable plays a significant role in explaining the effectiveness of the early warning system, for Jordan and Qatar. As well as, the results related to Jordan showed that the political stability indicators have an effect on the rate of inflation in consumer prices and the balance of payments index. Also, the result showed that the political stability indicators have no effect on the commodity and goods import index, the GDP, the commodity import index, and the commodity export index. On the other hand, the results related to Qatar showed that the indicators of political stability have an effect on the GDP, inflation rate in consumer prices the index of export of goods and services goods, and the commodity export index. Also, the results showed that the political stability indicators have no effect on the commodity and commodity import index.

By comparison between the effects of financial variables in each of the two countries, it noted that in Jordan, the most influential variable is the variable of importing goods, while the most influential variable in Qatar was the export of goods, before adding the variables related to the political stability of the model. But after adding the variables of political stability, the most influential variable in Jordan was the voice and accountability variable, while the most influential variable in Qatar was the regulatory quality variable.

It is noticeable when comparing the two countries before including the model for economic variables that the nature of the impact of economic variables is different as the index of the financial crisis in Jordan is affected by the import of goods and services while the most influential indicators in the early warning model for the occurrence of the financial crisis in Qatar is the index of exporting goods and services on the basis that the system Qatari financial is very sensitive to the subject of export of gas and oil.

It is also noticed that in both countries there is a very significant impact of political stability on the financial crisis, which is greater than the impact of economic indicators, and if the two countries differed in which indicators for political stability have the greatest impact on the occurrence of the financial crisis, in Jordan the most influential 
indicator was the government effectiveness variable in Qatar, the regulatory quality index was the most influential.

On other hand, and according to the criticality of this topic and the sample that used for investigating the Impact of Political Stability on the Effectiveness of the Early Warning Systems in Predicting the Financial Crises. The researcher experienced some difficulties and limitations. These limitations mainly represented by the nature of this topic, which makes it sensitive or close to economic and financial issues. This is because it deals with sensitive decisions and procedures of Political Stability and Early Warning Systems in Predicting the Financial Crises. There are also other limitations to rise while collecting data from the targeted sample. As the sample contained the data used in the empirical analysis is monthly data for both Jordan and Qatar, it is thus the researcher was Face some difficulties in collecting data.

Further research will be required in more than two countries. Future works could include a future exploration of this topic required deep empirical research in more than two countries, to obtain more generalizable results.

\section{References}

Al-Assaf, G. (2017). An Early Warning System for Currency Crisis: A Comparative Study for the Case of Jordan and Egypt. International Journal of Economics and Financial Issues, 7(3), 43-50

Al-Assaf, G., Al-Tarawneh, A., \& Alawin, M. (2013). Determinants of currency crisis in Jordan a multinomial logic model. European Scientific Journal, 9(34), 354-359.

Babecký, J., Havranek, T., Matějů, J., Rusnák, M., Šmídková, K., \& Vašíček, B. (2011). Early Warning Indicators of economic crises: evidence from a panel of 40 Developed countries. CNB WP, 8, 2011.

Beckmann, D., Menkhoff, L., \& Sawischlewski, K. (2006). Robust lessons about practical early warning systems. Journal of Policy Modeling, 28(2), 163-193.

Boonman, T. M., Kuper, G. H., Romero, A., \& Jacobs, J. P. (2017). Early Warning Systems for Currency Crises with Real-Time Data. CIRANO.

Çalışkan, Z. D. (2019). Political Stability and Financial Development: Evidence from Turkey. Fiscaoeconomia, 3(3), 72-79.

Campos, N. F., Nugent, J. B., \& Robinson, J. A. (1999). Can Political Instability be good for Growth? The Case of Meddle East and North Africa. Department of Economics, University of Southern California, Los Angeles, California.

Kamra, K. (2013). Debt Crisis Determinants: Early Warning Indicators for Emerging Markets. Doctoral dissertation, Tufts University.

Kaufmann, D., Kraay, A., \& Mastruzzi, M. (2010). The worldwide governance indicators: methodology and analytical issues. Hague Journal on the Rule of Law, 3(2), 220-246.

Kouba. L. \& Grochová. L. (2009). Financial crisis, political instability and economic growth. Mendel University in Brno Department of Economics Zemědělská 1, 61300 Brno, Czech Republic. Retrieved from http://www.opf.slu.cz/kfi/icfb/proc2011/pdf/26_Kouba.pdf

Tamadonejad, A., Abdul-Majid, M., Abdul-Rahman, A., Jusoh, M., \& Tabandeh, R. (2016). Early warning systems for banking crises? Political and economic stability. JurnalEkonomi Malaysia, 50(2), 31-38. 